\title{
Implementation of the learning process: Efforts to improve the quality of vocational education graduates
}

\author{
Ernawati Ernawati \\ Universitas Negeri Padang, Indonesia. \\ * Corresponding Author. Email: ernawati@fpp.unp.ac.id
}

\section{ARTICLE INFO \\ Article History \\ Received: \\ 26 September 2021, \\ Revised: \\ 5 October 2021; \\ Accepted: \\ 3 December 2021; \\ Available online: \\ 7 February 2022}

Keywords

Implementation;

Learning process;

Graduates;

Vocational education

\begin{abstract}
The quality of education is determined by a good management process, including the evaluation process of vocational education graduates. Furthermore, the purpose of this study is to evaluate the implementation of the learning process in vocational education programs, which includes an implementation of the teaching and learning process, the implementation of industrial training, lecturer skills in industrial supervision training, and encouraging entrepreneurship by lecturers to students. This study used a mixedmethod design, and data were collected by questionnaires and depthinterview questions. The sample size is 218 graduates successfully collected using the total sampling technique. Data analysis used quantitative descriptive statistics (SPSS 23.0) and qualitative descriptive. Qualitative data support the quantitative results through interviews with five research informants. The results showed that graduates agreed that the teaching and learning process, the implementation of industrial training, lecturer skills in industrial supervision training, encouraging entrepreneurship by lecturers to students had gone well. In conclusion, the implementation of the vocational education program has been following the program's objectives. However, the results of the study showed that there are still weaknesses in the guidance from lecturers to students in the practice of opening a business and updating developments in related industries. Based on the results of this study, recommendations are made to focus on improving the process of implementing vocational education programs.
\end{abstract}

This is an open access article under the CC-BY-SA license.

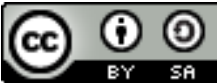

How to cite:

Ernawati, E. (2021). Implementation of the learning process: Efforts to improve the quality of vocational education graduates. Jurnal Pendidikan Vokasi, 11(3), 243-253. https://doi.org/10.21831/jpv.v11i3.44049

\section{INTRODUCTION}

Vocational education aims to generate graduates who are professional, broad-minded, skilled, and have entrepreneurial abilities. The education also aims to prepare graduates to become professionals in certain fields, have the ability to practice, develop knowledge and skills, and be able to improve people's living standards by providing employment opportunities (Eryanto et al., 2019; Imansari, 2017). Previous studies stated that the problems that arise in vocational education graduates are that the skills and competencies of graduates are still not satisfying the need of the industry and the number of graduates who become entrepreneurs after graduating from the diploma program still tends to be low (Dahalan et al., 2020. Ernawati et al., 2019, Eryanto et al., 2019, Imansari, 2017; Purwana et al., 2015; Zhao et al., 2018).

Ernawati et al., (2019), Eryanto et al. (2019), and Zhao et al. (2018) argued that motivation and desire for entrepreneurship were not the main factors causing the small number of graduates to 
become entrepreneurs. Research that has been carried out on entrepreneurial perceptions and motivations proves that student motivation was categorized as high in entrepreneurship, but the problem was the low number of diploma program graduates who become entrepreneurs. This indicates that the purpose of vocational education to create graduates who have entrepreneurial careers has not been achieved optimally. The problem of achieving educational goals is certainly rooted in the poor implementation of the education system (Areli et al., 2020; Okolie \& Ogbaekirigwe, 2014; Yuan et al., 2020; Zhao et al., 2018).

One of the efforts in finding solutions to these problems is through evaluating the implementation of vocational education programs to find out the problems and inequalities that occur in each component of the program that is a sub-system of this study program. Evaluation can provide recommendations and decisions on programs implemented to achieve program objectives (Haron et al., 2019). Efforts that policymakers can make to determine the skills of vocational education graduates require detailed and systematic research to ensure that program implementation continues to be guaranteed and the reliability of vocational education remains as an institution that is in line with the needs of the community and policymakers. However, there has been no systematic and observational study to evaluate this diploma program. Meanwhile, improving an educational program requires detailed and systematic research to ascertain the strengths and weaknesses of the program as well as the quality of vocational education.

Many studies are conducted to evaluate curriculum (Areli et al., 2020; Okolie \& Ogbaekirigwe, 2014; Sandroto et al., 2018). However, it has not explored in more detail the process aspects regarding the implementation of vocational education programs such as the Context, Input, Process, Product (CIPP) Evaluation Model by Stufflebeam (1971). In fact, many studies also prove that the Process aspect of CIPP is very important in growing and developing graduate competencies (Atmacasoy et al., 2018; Umam \& Saripah, 2018). Based on these problems, this study aims to evaluate the implementation of vocational education programs, especially the learning process aspect, which consists of the teaching and learning process, the implementation of industrial training, lecturer skills in industrial supervision training, and encouraging entrepreneurship by lecturers to students.

\section{RESEARCH METHOD}

This study used a mixed-method design, and data were collected by questionnaires and depth-interview questions. This design was very suitable to be used by researchers to explain research findings that agree or disagree even research findings that are significant or not significant (Creswell \& Clark, 2011). The population of the study was 241 graduates of D3 Fashion Design Department of Family Welfare, Faculty of Tourism and Hospitality, Universitas Negeri Padang. The sampling technique used is total sampling. However, only 218 respondents successfully filled out the questionnaire (response rate $=90.46 \%$ ). For the purposes of administering qualitative data, the researcher conducted individual interviews, and 5 participants agreed to be interviewed. In the interview method, researchers selected individuals who can help researchers understand key phenomena (Creswell, 2013). Interviews were recorded to facilitate interview transcripts provided. The quantitative data analysis technique used was descriptive analysis with a categorization method based on the average score assessment. The qualitative data analysis technique was carried out by reducing data, presenting data, and drawing conclusions.

\section{RESULT AND DISCUSSION}

Result

The descriptive statistic on the quantitative analysis was undertaken looking at the central tendency or the mean score and standard deviation on every item in each variable. The main purpose of this analysis is to understand the view of the respondents toward each item used. In other words, descriptive statistics enables the researcher to present the data in a more meaningful way, which allows a simpler interpretation of the data. It should be reaffirmed that this research focuses on the 
learning process to examine the variables of the implementation of the teaching and learning process, the implementation of industrial training, lecturer skills in industrial supervision training, and encouraging entrepreneurship by lecturers to students. Evaluation of the implementation of this aspect in education is carried out to improve the quality of vocational education graduates. The results and discussion of these four variables can be explained as follows.

\section{Teaching and Learning Process}

Table 1 reports the mean score rated by the respondent on items dealing with the teaching and learning process. The magnitude of the mean scores ranging from 3.61 to 4.07 out of five points on the Likert scale indicates that respondents agree on the items in this section.

Table 1. Results of Mean Score and Standard Deviation of the Implementation of the Teaching and Learning Process

\begin{tabular}{llrr}
\hline No. & \multicolumn{1}{c}{ Items } & M & SD \\
\hline 1. & The entrepreneurial learning offered prepares you to become an entrepreneur & 3.92 & .742 \\
2. & The implementation of learning follows the course synopsis & 3.61 & .819 \\
3. & Entrepreneurial learning has clear rules & 3.76 & .866 \\
4. & Computers are provided to make it easier for lecturers to carry out entrepreneurial & 3.88 & .725 \\
& learning & & \\
5. & Lecturers present appropriate material and can open students' horizons to become & 3.84 & .727 \\
6. & entrepreneurs & 3.99 & .643 \\
7. & Teaching and learning often use pictorial media & 4.00 & .629 \\
8. & Lecturers use teaching and learning materials obtained from various sources & .657 \\
9. & Learning activities are guided by the curriculum provided by the faculty & 4.07 & .657 \\
10. & Lecturers guide students while conducting the entrepreneurial practice in the field & 3.99 & .727 \\
& of fashion studies & 3.77 & .831 \\
11. & Lecturers always arouse students' interest in opening a business in the field of \\
& fashion/clothing studies & 3.87 & .826 \\
& $\quad$ Overall & 3.88 & .494 \\
\hline
\end{tabular}

Note:

$\mathrm{SA}=$ Strongly Agree; $\mathrm{A}=$ Agree; $\mathrm{N}=$ Neutral $; \mathrm{D}=$ Disagree; $\mathrm{SDs}=$ Strogly Disagree; $\mathrm{SD}=$ Standard Deviation $\mathrm{N}=218$

Respondents ever felt that lecturers often associate learning with current or recent entrepreneurial issues ( $M=4.07$, Item 8), lecturers use teaching and learning materials obtained from various sources ( $M=4.00$, Item 7), teaching and learning often use pictorial media $(M=3.99$, Item 6), and learning activities are guided by the curriculum provided by the faculty ( $M=3.99$, Item 9$)$. Similarly, respondents agreed that the entrepreneurial learning offered prepares you to become an entrepreneur $(\mathrm{M}=3.92$, Item 1$)$, computers are provided to make it easier for lecturers to carry out entrepreneurial learning $(\mathrm{M}=3.88$, Item 4$)$, lecturers always arouse students' interest in opening a business in the field of fashion/clothing studies $(\mathrm{M}=3.87$, Item 11) and lecturers present appropriate material and can open students' horizons to become entrepreneurs $(\mathrm{M}=3.84$, Item 5).

Further agreements were given to the three items whereby lecturers guide students while conducting the entrepreneurial practice in the field of fashion studies $(\mathrm{M}=3.77$, Item 10), entrepreneurial learning has clear rules $(\mathrm{M}=3.76$, Item 3$)$, and the implementation of learning follows the course synopsis $(\mathrm{M}=3.61$, Item 2$)$. Overall, the average value of the process aspects of the teaching and learning process variables obtained an average score of 3.88, which explained that overall, respondents agreed on the items in the process of implementing the teaching and learning process. What could be said from the overall result is that aspects of the learning process for the implementation of the teaching and learning process have been going well.

Based on data reduction and display data, the results obtained from qualitative data through interviews concluded that all interviewed graduates admitted that the graduates agreed with the implementation of the teaching and learning process taken during the D3 fashion design program at Family Welfare, Faculty of Tourism and Hospitality, Universitas Negeri Padang. According to A1, 
A2, A3, A4, and A5, the implementation of the teaching and learning process can increase students' interest in entrepreneurship. They also suggested that the implementation of the teaching and learning process needs to be improved both the material and the learning media. What is no less important is that during the practice of entrepreneurship, it is still necessary to improve the quality of learning so that it really opens students' horizons to become entrepreneurs in the fashion field.

\section{Implementation of Industrial Training}

This section analysis looks at the perception of respondents toward the implementation of industrial training. The overall mean scores ranging from 3.72 to 4.05 in Table 2 show that the graduates D3 Fashion Design program at the Faculty of Tourism and Hospitality, Universitas Negeri Padang agreed with all items probed in this section.

Table 2. Results of Mean Score and Standard Deviation of the Implementation of the Industrial Training

\begin{tabular}{llcc}
\hline No. & \multicolumn{1}{c}{ Items } & M & SD \\
\hline 1. & Industrial training improved my mastery of entrepreneurial knowledge & 3.72 & .597 \\
2. & Gain a lot of knowledge related to the production process easily & 3.94 & .722 \\
3. & Able to learn effective ways to handle customer complaints & 3.91 & .787 \\
4. & Industrial training is a learning method that helps me in real situations & 4.05 & .780 \\
5. & The implementation of industrial training made me proficient on how to be an & 3.95 & .726 \\
6. & Antrepreneur & 3.90 & .740 \\
7. & Get a lot of information needed by the field of study & 3.95 & .720 \\
8. & Get a lot of information about the type of machine/technology that is appropriate to & 3.90 & .715 \\
& produce clothing products & & \\
9. & Get a lot of information about entrepreneurial opportunities in various fields of & 3.72 & .771 \\
10. & Able to learn new techniques that can complement existing skills & 3.73 & .821 \\
11. & Able to apply the knowledge possessed to the types of training implemented in the & 3.73 & .826 \\
12. & Industry & 3.74 & .889 \\
13. & Industrial training adds to the consolidation of knowledge and skills & 3.90 & .737 \\
14. & More confident to work alone after undergoing industrial training & 3.80 & .737 \\
15. & Able to improve skills learned during the implementation of industrial training & 3.90 & .727 \\
16. & Activities during industrial training provide many new experiences & 3.94 & .696 \\
17. & Industrial training provides many new experiences & 4.01 & .773 \\
18. & Industrial training has eliminated the negative nature of the self & 3.99 & .788 \\
& $\quad$ Overall & 3.88 & .412 \\
\hline
\end{tabular}

Note:

$\mathrm{SA}=$ Strongly Agree; $\mathrm{A}=$ Agree $; \mathrm{N}=$ Neutral $; \mathrm{D}=$ Disagree $; \mathrm{SDs}=$ Strogly Disagree $\mathrm{SD}=$ Standard Deviation $\mathrm{N}=218$

Respondents agreed that industrial training is a learning method that helps me in real situations ( $\mathrm{M}=4.05$, Item 4$)$, industrial training provides many new experiences ( $\mathrm{M}=4.01$, Item 17), industrial training has eliminated the negative nature in the self $(\mathrm{M}=3.99$, Item 18), the implementation of industrial training made me proficient on how to be an entrepreneur $(M=3.95$, Item 5) and get a lot of information needed by the field of study $(\mathrm{M}=3.95$, Item 7). With such perceptions, they admitted that gain a lot of knowledge related to the production process easily $(\mathrm{M}=3.94$, Item 2), activities during industrial training provide many new experiences ( $\mathrm{M}=3.94$, Item 16), able to learn effective ways to handle customer complaints ( $\mathrm{M}=3.91$, Item 3$)$, able to learn to identify business opportunities during industrial training $(\mathrm{M}=3.90$, Item 6$)$ and get a lot of information about the type of machine or technology that is appropriate to produce clothing products ( $M=3.90$, Item 8). 
Respondents seemed to agree that industry training is useful for synchronizing knowledge with skills $(\mathrm{M}=3.90$, Item 13), able to improve skills learned during the implementation of industrial training $(\mathrm{M}=3.90$, Item 15$)$, more confident to work alone after undergoing industrial training $(\mathrm{M}=3.80$, Item 14), industrial training adds to the consolidation of knowledge and skills $(\mathrm{M}=3.74$, Item 12) and able to learn new techniques that can complement existing skills ( $M=3.73$, Item 10). Further agreements were given to the three items whereby they agreed that able to apply the knowledge possessed to the types of training implemented in the industry ( $M=3.73$, Item 11), industrial training improved my mastery of entrepreneurial knowledge $(\mathrm{M}=3.72$, Item 1$)$, and get a lot of information about entrepreneurial opportunities in various fields of business ( $M=3.72$, Item 9). Overall, the average value of the process aspects of the implementation of the industrial training variables obtained an average score of 3.88 , which explained that overall, respondents agreed on the items in the process of implementing the industrial training. What could be said from the overall result is that aspects of the learning process for the implementation of industrial training have also been going well.

Based on data reduction and display data, the results obtained from qualitative data through interviews concluded that all the interviewed graduates admitted that they agreed with the implementation of industrial training during the D3 Fashion Design Department of Family Welfare, Faculty of Tourism and Hospitality, Universitas Negeri Padang. A1, A2, A3, A4, and A5 conveyed that industrial training can increase students' interest in entrepreneurship. They also suggested that the implementation of industrial training needs to be maintained because, in the implementation of industrial training, a lot of information is needed to become an entrepreneur.

\section{Lecturer Skills in Supervision Industrial Training}

Table 3 displays the overall mean score rated by the respondents dealing with lecturer skills in industrial supervision training. The overall mean scores in Table 3 show that the graduates D3 Fashion Design program at JKK FPP UNP agreed with all items probed in this section. This is evident through the magnitude of the mean score, which ranges from 3.70 to 4.05 out of the five points of the Likert scale. Obviously, the majority of the respondents in this study agreed that lecturers could encourage industry leaders to provide motivation to carry out industrial training ( $M=4.05$, Item 13), lecturers experience with industry helps identify entrepreneurial opportunities that are relevant to the knowledge being studied ( $\mathrm{M}=3.82$, Item 9), lecturers always find solutions to problems faced in carrying out industrial training $(\mathrm{M}=3.78$, Item 6), lecturers always discuss the procedures for industrial training activities $(\mathrm{M}=3.78$, Item 7$)$ and lecturers always provide support in identifying activities that can be carried out in the industrial field $(\mathrm{M}=3.77$, Item 8).

Similarly, they agreed that lecturers could identify the problems encountered while carrying out industrial training $(\mathrm{M}=3.75$, Item 2$)$, lecturers show positive thoughts while carrying out industrial training $(\mathrm{M}=3.75$, Item 4$)$, lecturers and industry leaders always provide examples of types of businesses that are following the field of fashion studies $(M=3.75$, Item 11), lecturer's guide carrying out industrial training on an ongoing basis $(\mathrm{M}=3.74$, Item 5) and lecturers work well with industry leaders $(\mathrm{M}=3.73$, Item 10$)$. They also agreed that lecturers always provide moral support in carrying out industrial training $(\mathrm{M}=3.72$, Item 3$)$, lecturers collaborate with industry leaders in supervision when carrying out industrial training $(\mathrm{M}=3.71$, Item 12), and lecturers guide cooperatively during industrial training $(\mathrm{M}=3.70$, Item 1$)$.

Overall, the average value of the process aspects of the implementation of the lecturer skills in supervision industrial training variables obtained an average score of 3.77, which explained that overall respondents agreed on the items in the process of implementing the lecturer skills in industrial supervision training. This result manifestly shows that aspects of the learning process for implementing the lecturer skills in industrial supervision training have also been going well. 
Table 3. Results of Mean Score and Standard Deviation of the Implementation of the Lecturer Skills in Supervision Industrial Training

\begin{tabular}{|c|c|c|c|}
\hline No. & Items & $\mathrm{M}$ & SD \\
\hline 1. & Lecturers guide cooperatively during industrial training & 3.70 & .628 \\
\hline 2. & $\begin{array}{l}\text { Lecturers can identify the problems encountered while carrying out industrial } \\
\text { training }\end{array}$ & 3.75 & .743 \\
\hline 3. & Lecturers always provide moral support in carrying out industrial training & 3.72 & .766 \\
\hline 4. & Lecturers show positive thoughts while carrying out industrial training & 3.75 & .685 \\
\hline 5. & Lecturer's guide carrying out industrial training on an ongoing basis & 3.74 & .740 \\
\hline 6. & Lecturers always find solutions to problems faced in carrying out industrial training & 3.78 & .788 \\
\hline 7. & Lecturers always discuss the procedures for industrial training activities & 3.78 & .780 \\
\hline 8. & $\begin{array}{l}\text { Lecturers always provide support in identifying activities that can be carried out in } \\
\text { the industrial field }\end{array}$ & 3.77 & .692 \\
\hline 9. & $\begin{array}{l}\text { Lecturers experience with industry helps identify entrepreneurial opportunities that } \\
\text { are relevant to the knowledge being studied }\end{array}$ & 3.82 & .747 \\
\hline 10. & Lecturers work well with industry leaders & 3.73 & .786 \\
\hline 11. & $\begin{array}{l}\text { Lecturers and industry leaders always provide examples of types of businesses that } \\
\text { are in accordance with the field of fashion studies }\end{array}$ & 3.75 & .750 \\
\hline 12. & $\begin{array}{l}\text { Lecturers collaborate with industry leaders in supervision when carrying out } \\
\text { industrial training }\end{array}$ & 3.71 & .725 \\
\hline \multirow[t]{2}{*}{13.} & $\begin{array}{l}\text { Lecturers can encourage industry leaders to provide motivation to carry out } \\
\text { industrial training }\end{array}$ & 4.05 & .680 \\
\hline & Overall & 3.77 & 0.496 \\
\hline
\end{tabular}

Note:

$\mathrm{SA}=$ Strongly Agree; $\mathrm{A}=$ Agree $; \mathrm{N}=$ Neutral $; \mathrm{D}=$ Disagree $; \mathrm{SDs}=$ Strogly Disagree $\mathrm{SD}=$ Standard Deviation $\mathrm{N}=218$

Based on data reduction and display data, the results obtained from qualitative data through interviews concluded that some of the graduates interviewed admitted that industrial skills development was carried out by lecturers while attending lectures from the D3 Fashion Design Department of Family Welfare, Faculty of Tourism, and Hospitality, Universitas Negeri Padang. According to A1, A2, A3, A4, and A5 conveyed that the development of industrial supervision skills by lecturers can increase student interest in conducting industrial development. However, some of the graduates interviewed admitted that the industrial supervision skills provided by the lecturers during the D3 Fashion Design education program have not produced good and maximum results. All students need guidance from lecturers because the guidance of lecturers will determine the success of students in carrying out industrial training. In contradiction with the quantitative result, it was found that there are still lecturers who do not provide guidance while students carry out industrial training.

\section{Encouraging Entrepreneurship by Lecturers to Students}

Table 4 displays the overall mean score rated by the respondents regarding encouraging entrepreneurship by lecturers to students. Out of eleven items posed, four items were rated as neutral, and seven items received the level of agreement by the respondents. This is evident through the magnitude of the mean score, which ranges from 2.78 to 3.80 out of the five points of the Likert scale. As such, respondents neutral that lecturers always provide feedback regarding achievements in implementing entrepreneurial practices $(\mathrm{M}=3.50$, Item 5), lecturers always inform the latest developments in the fashion business $(\mathrm{M}=3.10$, Item 11), lecturers always lend entrepreneurship books to discuss $(\mathrm{M}=2.86$, Item 1$)$ and lecturers guide students when carrying out teaching and learning activities of business practice $(\mathrm{M}=2.78$, Item 9$)$.

Despite these, the respondents agreed that lecturers always increase interaction when carrying out entrepreneurial practices $(\mathrm{M}=3.80$, Item 6$)$, students are given the opportunity to discuss 
ideas and experiences with lecturers $(M=3.75$, Item 7), lecturers help to identify and find solutions if they find problems in learning $(\mathrm{M}=3.71$, Item 2$)$ and lecturers always talk to the group how to carry out entrepreneurial practices learning $(\mathrm{M}=3.70$, Item 4$)$. The respondents also agreed that together, the lecturers teach how to run an effective business ( $\mathrm{M}=3.69$, Item 3$)$, lecturers always give advice related to entrepreneurial work $(\mathrm{M}=3.66$, Item 8$)$, and lecturers are open to criticism in learning $(\mathrm{M}=3.67$, Item 10).

Overall, the average value of the process aspects of the implementation of the encouraging entrepreneurship by lecturers to students' variables obtained an average score of 3.50, which explained that overall respondents were neutral on the items in the process of implementing the encouraging entrepreneurship by lecturers to students. This result manifestly shows that aspects of the learning process for implementing the lecturer skills in industrial supervision training have been slightly going well.

Table 4. Results of Mean Score and Standard Deviation of the Implementation of the Encouraging Entrepreneurship by Lecturers to Students

\begin{tabular}{|c|c|c|c|}
\hline No. & Items & $\mathrm{M}$ & SD \\
\hline 1. & Lecturers always lend entrepreneurship books to discuss & 2.86 & .836 \\
\hline 2. & Lecturers help to identify and find solutions if they find problems in learning & 3.71 & 763 \\
\hline 3. & Together, the lecturers teach how to run an effective business & 3.69 & .692 \\
\hline 4. & $\begin{array}{l}\text { Lecturers always talk to the group about how to carry out entrepreneurial } \\
\text { practices }\end{array}$ & 3.70 & .702 \\
\hline 5. & $\begin{array}{l}\text { Lecturers always provide feedback regarding achievements in implementing } \\
\text { entrepreneurial practices }\end{array}$ & 3.50 & .680 \\
\hline 6. & Lecturers always increase interaction when carrying out entrepreneurial practices & 3.80 & .793 \\
\hline 7. & Students are given the opportunity to discuss ideas and experiences with lecturers & 3.75 & .809 \\
\hline 8. & Lecturers always give advice related to entrepreneurial work & 3.66 & .706 \\
\hline 9. & $\begin{array}{l}\text { Lecturers guide students when carrying out teaching and learning activities of } \\
\text { business practice }\end{array}$ & 2.78 & .714 \\
\hline 10. & Lecturers are open to criticism in learning & 3.67 & .772 \\
\hline 11. & Lecturers always inform the latest developments in the fashion business & 3.10 & 742 \\
\hline & Overall & 3.50 & .449 \\
\hline
\end{tabular}

Note:

$\mathrm{SA}=$ Strongly Agree; $\mathrm{A}=$ Agree $; \mathrm{N}=$ Neutral $; \mathrm{D}=$ Disagree; $\mathrm{SDs}=$ Strogly Disagree; $\mathrm{SD}=$ Standard Deviation $\mathrm{N}=218$

Based on data reduction and display data, the results obtained from qualitative data through interviews concluded that some of the graduates interviewed agreed that encouragement of entrepreneurship by the lecturers to their students in achieving the program goals carried out during the D3 Fashion Design Department of Family Welfare, Faculty of Tourism, and Hospitality, Universitas Negeri Padang. According to A1, A2, and A5, lecturers always encourage their students to achieve program goals. Lecturers also act as role models for their students.

\section{Discussion}

\section{Teaching and Learning Process}

Based on the result, respondents agreed on the items in the process of implementing the teaching and learning process. This means that the learning process has been carried out well. This result is strengthened by the results obtained from interviews in which graduates also agreed on the items in the process of implementing the teaching and learning process. From the overall results obtained that the teaching and learning process has been carried out well but needs improvement on material and the learning media teaching and learning process to increase students' interest in entrepreneurship. 
A good teaching and learning process will impact students' interest in pursuing a career as an entrepreneur in the fashion business. This result is well corroborated with Lang and Liu (2019) that good entrepreneurial education planning impacts graduates' interest in entrepreneurship. This is supported by Hidayah (2020) that using the latest project-based learning model in the teaching and learning process improves the readiness of graduates in entrepreneurship.

\section{Implementation of Industrial Training}

Based on the result, respondents agreed on the items in the process of implementing the industrial training. This means that the industrial training program has been carried out well. This result is strengthened by the results obtained from interviews in which graduates also agreed on the items in implementing the industrial training. From the overall results obtained that the industrial training program has been carried out well. The implementation of industrial training needs to be maintained because a lot of information is needed to become an entrepreneur in the implementation of industrial training. Industrial training has a segment of education and training, between education and training, which are interrelated. The training aims to improve skills and learn to improve and develop attitudes, values, and experiences to be more productive. This study aligns with Mawonedzo et al. (2021) that the experiential learning gained from industrial attachment is necessary for students to become future entrepreneurs in fashion design.

\section{Lecturer Skills in Supervision Industrial Training}

Based on the result, respondents agreed on the items in the process of implementing the lecturer skills in industrial supervision training. This means that lecturers have applied their skills in supervision students during the implementation of industrial training well. This result is slightly contradicted by the results obtained from interviews in which graduates suggested that students need guidance from lecturers because the guidance of lecturers will determine the success of students in carrying out industrial training. The result also found that there are still lecturers who do not provide guidance while students carry out industrial training. Even though the existence of good guidance by lecturers in the implementation of industrial training has an impact on the achievement of students' abilities in entrepreneurship. This result is contradicted with Donkor et al. (2009) that lecturer skills in guidance or supervision during practical in the industry is very necessary to ensure the achievement of competencies obtained by students.

\section{Encouraging Entrepreneurship by Lecturers to Students}

Based on the result, overall respondents were neutral on the items in the process of implementing the encouraging entrepreneurship by lecturers to students. This result showed that implementing the lecturer skills in industrial supervision training has been slightly going well. Based on the interview result, the graduates agreed that encouragement of entrepreneurship by the lecturers to their students in achieving the program goals which were carried out during the D3 Fashion Design Department of Family Welfare, Faculty of Tourism, and Hospitality, Universitas Negeri Padang.

From the results of this study, graduates have not felt strongly encouraged entrepreneurship by lecturers to students. It is necessary to increase lecturers' understanding in providing entrepreneurial encouragement to students during student education programs. This is in line with the position of lecturers as educators who can transfer knowledge as well as become models in learning. Committed lecturers can provide encouragement and guidance related to entrepreneurship courses and student success. Entrepreneurship education aims to develop the potential of students to be more creative and innovative, educate someone to be ready to identify opportunities and seize opportunities in their environment, translate ideas into reality or economic activities, and be able to survive and be sensitive to changes. The lack of a harmonious relationship between lecturers and students in carrying out specific learning causes problems for students, making students less interested in entrepreneurship. In addition, lecturers must also provide clear explanations regarding the tasks assigned to their students and encourage a harmonious relationship. 


\section{CONCLUSION}

Based on the results of quantitative analysis that the average graduate agreed that the learning process in D3 Fashion Design Department of Family Welfare, Faculty of Tourism, and Hospitality, Universitas Negeri Padang has been carried out well, this was also confirmed through interviews for qualitative analysis which explained that the informants had experienced a good learning process while being a student in the program. Evaluation of the implementation of the learning process, which is viewed from teaching and learning process, the implementation of industrial training, lecturer skills in industrial supervision training, and encouraging entrepreneurship by lecturers to students it also has been implemented well, but improvements need to be made for each of the variables involved.

The improvements made such as the use of the latest teaching and learning processes, optimizing the use of industrial training, equalizing the perception of lecturers in providing assistance to students during industrial training, and increasing the entrepreneurial encouragement by lecturers to students through programs carried out during education program will have an impact on achievement competence of graduates in entrepreneurship in the fashion sector and also improve the quality of graduates as vocational study programs. This result is in line with Iwu et al. (2021) that the perceived competence of lecturers showed a moderate and positive correlation with the entrepreneurial intentions of students. Encouragement from lecturers in the learning process can kindle the entrepreneurial intention flame in students..

\section{REFERENCES}

Areli, A. J., Lian, B., \& Kristiawan, M. (2020). An evaluation of implementation industrial work practice programs in vocational school. International Journal of Progressive Sciences and Technologies, 20(2), 179-186. https://doi.org/10.52155/ijpsat.v20.2.1802

Atmacasoy, A., Ok, A., \& Şahin, G. (2018). An evaluation of introduction to industrial engineering course at Sabanc1 University using CIPP model. Engineering Education for Sustainable Development Conference (EESD 2018), 181-188. https://research.sabanciuniv.edu/36148/1/EESD2018Proceedings_Atmacasoyetal_IIE.pdf

Creswell, J. W. (2013). Qualitative inquiry and research design: Choosing among five approaches (3rd ed.). SAGE Publications, Inc.

Creswell, J. W., \& Clark, V. L. P. (2011). Designing and conducting mixed methods research. SAGE Publication.

https://www.google.co.id/books/edition/Designing_and_Conducting_Mixed_Methods_R/6 tYNo0UpEqkC?hl=en\&gbpv=0

Dahalan, D., D’Silva, J. L., Ismail, I. A., \& Mohamed, N. A. (2020). Entrepreneurship readiness among students of Technical and Vocational Education and Training (TVET) Institutions in Malaysia. International Journal of Academic Research in Business and Social Sciences, 10(15), 164-175. https://doi.org/10.6007/IJARBSS/v10-i15/8241

Donkor, F., Nsoh, S. N., \& Mitchual, S. J. (2009). Assessment of a supervised industrial attachment of a technical and vocational teacher education program in Ghana. Asia-Pacific Journal of Cooperative Education, 10(1), 1-17. http://www.apjce.org/files/APJCE_10_1_1_17.pdf

Ernawati, E., Buang, N. A., Yulastri, A., \& Ganefri, G. (2019). Entrepreneurship career choice and its influencing factors among the graduates of diploma in fashion and design from University of Padang, Indonesia. International Journal of Innovative Technology and Exploring Engineering (IJITEE), 8(7S2), 344-349. https://www.ijitee.org/wpcontent/uploads/papers/v8i7s2/G10600587S219.pdf

Eryanto, H., Swaramarinda, D. R., \& Nurmalasari, D. (2019). Effectiveness of entrepreneurship practice program: using CIPP program evaluation. Journal of Entrepreneurship Education, 
22(1), 1-10. https://www.abacademies.org/articles/effectiveness-of-entrepreneurshippractice-program-using-cipp-program-evaluation-7572.html

Haron, H., Hussain, M., Ali, A., Rus, C., \& Zulkifli, M. (2019). The importance of generic skills for technical and vocational students employability. International Journal of Academic Research in Business and Social Sciences, 9(7), 33-45. https://doi.org/10.6007/IJARBSS/v9-i7/6089

Hidayah, H. N. (2020). Precondition model for field work practices based on project-based learning to improve vocational school stundents' competence and readiness in entrepreneurship, fashion design expertise program. Journal of Vocational and Career Education, 5(2), 128139. https://doi.org/10.15294/jvce.v5i2.29366

Imansari, F. I. (2017). The impact of entrepreneurship education to entrepreneurial intention and motivation. Proceedings of the 2nd International Conference on Economic Education and Entrepreneurship (ICEEE 2017), 257-262. https://www.scitepress.org/Papers/2017/69809/69809.pdf

Iwu, C. G., Opute, P. A., Nchu, R., Eresia-Eke, C., Tengeh, R. K., Jaiyeoba, O., \& Aliyu, O. A. (2021). Entrepreneurship education, curriculum and lecturer-competency as antecedents of student entrepreneurial intention. The International Journal of Management Education, 19(1), 100295. https://doi.org/10.1016/j.ijme.2019.03.007

Lang, C., \& Liu, C. (2019). The entrepreneurial motivations, cognitive factors, and barriers to become a fashion entrepreneur: A direction to curriculum development for fashion entrepreneurship education. International Journal of Fashion Design, Technology and Education, 12(2), 235-246. https://doi.org/10.1080/17543266.2019.1581844

Mawonedzo, A., Tanga, M., Luggya, S., \& Nsubuga, Y. (2021). Implementing strategies of entrepreneurship education in Zimbabwe. Education + Training, 63(1), 85-100. https://doi.org/10.1108/ET-03-2020-0068

Okolie, U. C., \& Ogbaekirigwe, C. (2014). Entrepreneurship development through vocational education training: Issues and roles in skills acquisition and manpower development in a developing economy. Journal of Educational Policy and Entrepreneurial Research (JEPER), 1(2), 151-157. http://jeper.org/index.php/JEPER/article/view/28

Purwana, D., Suhud, U., \& Arafat, Y. M. (2015). Taking/Receiving and Giving (TRG): A comparison of two quantitative pilot studies on students' entrepreneurial motivation in Indonesia. International Journal of Research Studies in Management, 4(1), 3-14. https://www.researchgate.net/profile/Dedi-

Purwana/publication/273299848_Takingreceiving_and_giving_TRG_A_comparison_of_t wo_quantitative_pilot_studies_on_students'_entrepreneurial_motivation_in_Indonesia/link $\mathrm{s} / 565 \mathrm{c} 2 \mathrm{c} 5208 \mathrm{aefe} 619 \mathrm{~b} 251 \mathrm{f} 50 /$ Taking-receiving-and-

Sandroto, C. W., Riyanti, B. P. D., \& Warmiyati, M. T. (2018). Entrepreneurial intention and competencies of vocational and high school graduates in Indonesia. Pertanika Journal of Social Sciences \& Humanities, 26(Special Issue), 225-236. https://web.p.ebscohost.com/abstract?site=ehost\&scope $=$ site $\& j$ rnl $=01287702 \&$ AN $=13408$ 1850\&h=H2Og87\%2BBOPosis8I6sIE\%2BL39rdDr0eUFw14Q22vottr3gdasNLoe\%2FBcp pOmmelzzpyCxJeRp9JVKlhQn33JbMg\%3D\%3D\&crl=c\&resultLocal=ErrCrlNoResults\& resultNs=Ehost\&crlhashurl=login.as

Stufflebeam, D. L. (1971). The relevance of the CIPP evaluation model for educational accountability. The Annual Meeting of the American Association of School Administrators, 1-30. https://files.eric.ed.gov/fulltext/ED062385.pdf

Umam, K. A., \& Saripah, I. (2018). Using the Context, Input, Process and Product (CIPP) model in the evaluation of training programs. International Journal of Pedagogy and Teacher Education, 2, 183-194. https://doi.org/10.20961/ijpte.v2i0.26086 
Yuan, C.-H., Wang, D., Mao, C., \& Wu, F. (2020). An empirical comparison of graduate entrepreneurs and graduate employees based on graduate entrepreneurship education and career development. In Sustainability (Vol. 12, Issue 24). https://doi.org/10.3390/su122410563

Zhao, S., Zhang, H., \& Wang, J. (2018). Cognition and system construction of civil engineering innovation and entrepreneurship system in emerging engineering education. Cognitive Systems Research, 52, 1020-1028. https://doi.org/10.1016/j.cogsys.2018.10.020 